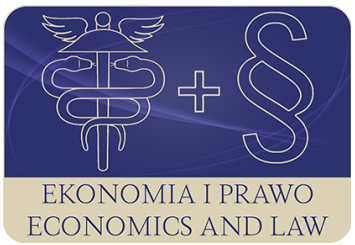

EKONOMIA I PRAWO. ECONOMICS AND LAW

Volume 20, Issue 1, March 2021

p-ISSN 1898-2255, e-ISSN 2392-1625

www.economicsandlaw.pl

EKONOMIA I PRAWO

ORIGINAL ARTICLE

received 06.10.2020; revised 20.03.2021; accepted 31.03.2021

Citation: Cyrek, M.(2021). Sectoral structure of employment and economic cohesion in the EU

regions. Ekonomia i Prawo. Economics and Law, 20(1): 63-77. doi:10.12775/EiP.2021.004.

\title{
Sectoral structure of employment and economic cohesion in the EU regions
}

\author{
MAGDALENA CYREK \\ University of Rzeszów, Institute of Economics and Finance, ul. Ćwiklińnkiej 2, 35-601 Rzeszów, \\ Poland \\ $\square$ mcyrek@ur.edu.pl \\ orcid.org/0000-0001-5020-9273
}

\begin{abstract}
Motivation: Regional cohesion constitutes an important aim of European policy. Nevertheless, it is mainly assessed in terms of economic results analyzed at an aggregate level. Sectoral determinants of interregional differences are often neglected. However, as the structural convergence concept suggests, sectoral features may be decisive for minimizing interregional disparities.

Aim: The paper searches for connections between two dimensions of economic regional cohesion in the EU: economic results and structural features. It tests a hypothesis about the coexistence of high diversification in GDP per capita and in the sectoral structures of employment. It is also aimed at identification of sectoral features that characterize the best performing economies.

Results: The research results confirm a positive correlation between interregional differences in production and in sectoral structures. It indicates knowledge-intensive market services as a sector the most favorable for economic results. Moreover, it also finds that a high concentration of sectoral structures coexists with a high level of regional GDP per capita and economic efficiency.
\end{abstract}

Keywords: economic cohesion; sectoral structure; efficiency; regions

JEL: O14; O18; O47; O52; R10 


\section{Introduction}

The problem of regional cohesion and the processes of regional convergence are the focus of attention of numerous researchers and of interest to politicians. Although cohesion is more than a purely economic phenomena, it is very often translated into coherence of GDP levels (see e.g. Monfort, 2008). In this vein, economic cohesion may be defined as a state of slight and acceptable differences between regional GDP per capita (e.g. Molle \& Boeckhout, 1995, p. 106), while regional convergence may be understood as a process of equalizing the GDP per capita levels (Monfort, 2008). Although the terms are often used interchangeably, there appears a slight difference that manifests in the analytical approach. The former is analyzed in static terms by comparing the actual economic condition of the regions and the later by taking a dynamic approach that involves adopting the idea of $\beta$ or $\sigma$ convergence. The paper takes the static approach and attempts to diagnose the state of economic cohesion between regions in the EU. However, it is not reduced to the purely real production dimension but takes into account also the coherence of the sectoral structures of employment.

The paper focuses on the structural dimension of the interregional disparities in the EU specified by sectoral employment. It attempts to find the relationships between the level of interregional structural diversification and the scale of differences in regional economic results. Thus it empirically verifies a hypothesis about the coexistence of the structural differences in terms of sectoral employment and the differences in GDP per capita levels.

It also aims to specify those structural features that characterize the best performing economies. It tries to identify sectors that are typical in regions with the highest GDP per capita as well as those enabling regions to use labor in the most efficient way. Moreover, it searches for relationships between economic results and structural concentration. It verifies a hypothesis about specialization as a structural feature of economies with high GDP per capita and economic efficiency compared to one stating that the regions with diversified structure of employment are those the best performing.

The results are of great importance for the practice of the European cohesion policy. They allow one to conclude whether the policy should focus on the structural features of regional economies to minimize developmental disparities. Moreover, the research may specify directions of the policy shaping economic structures favorable for economic development.

\section{Literature review}

The paper ties in with two main strands found in the literature, both connected with the disaggregated approach to economic cohesion and convergence. The first covers the sectoral approach and research on structural transformation. It stems from works by Fisher (1935), Clark (1940) and Fourastié (1949), 
as well as Kuznets (1966) and Chenery (1971), who specify a universal pattern of structural development from agriculture towards industry and services. It induced the concept of sectoral convergence and the 'cost disease' described by Baumol (1967) which, assuming low productivity growth in services, results in slower growth of advanced economies and growing prices of services. Both the structural pattern as well as its consequences are widely discussed and browsed (e.g. Fuchs, 1965; Klodt, 1995; Rowthorn \& Ramaswamy, 1997), and are mainly shaped by a need to disaggregate the service sector and the search for new growth poles. Nowadays, the most often suggested solution is to adopt the idea of the differing knowledge-intensity of activities; however, no common consensus about detailed subsectors has been achieved.

The second strand of the literature is specified by a regional approach to convergence. Many authors pay attention to empirically identified differences between state and regional processes. It is often claimed that convergence prevails at the national level while regional economies diverge (Longhi \& Musolesi, 2007, pp. 333, 336; Neculita \& Sarpe, 2019, pp. 12-19). Nevertheless, research into regional convergence in the EU leads to ambiguous results. Most suggest prevailing regional divergence; however, the conclusions differ concerning the period of analysis as well as their geographical coverage.

Moreover, by combining the structural and the regional issues, a concept for structural convergence was defined by Wacziarg (2001). The idea assumes that if structural differences narrow along with income per capita convergence, one can find structural convergence. In this vein, the specialization-diversification issue is widely discussed, initiated by the work of Krugman (1991) and a new economic geography development.

The existence of structural convergence and the role of sectoral composition for the economic convergence of regions have been tested by many researchers. Iordan et al.(2017, p. 36) claim to have found correlations between structural and income (real) convergence, although the findings differ in terms of the strength and direction of such a connection. Research by Guastella and Timpano (2016) for regions in Europe supports the thesis that the gaps in the economic structure are responsible for the persistence of income disparities. Sassi (2011, pp. 101-115) also stresses the significance of structural composition and its transformation for regional convergence in the EU.

Concerning the specialization-diversification issue the results are more ambiguous. Differences in specialization patterns were found within the EU regions at different stages of integration (e.g. Bierbaumer-Polly et al., 2016, pp. 544-568). The results by Longhi and Musolesi (2007, pp. 333-351) support the thesis that structural diversification appears to be more favorable for regional development. Similar conclusions were drawn by Kallioras and Petrakos (2010, pp. 667-680), who also state that diversification seems to be more favorable for regional growth in the EU. Simultaneously they point out that the kind of specialization may be decisive for the growth, as capital-intensive sector development may be growth stimulating. On the other hand, Krieger-Boden's (2004) 
analyses for selected European regions indicate moderate degrees of specialization and its minor influence on the evolution of regions and industries.

Generally, the conclusions from research into the structural determinants of regional convergence usually concern creating an appropriate economic policy. Most of the results underline the need to place more emphasis on a diverse industrial structure in regional economies when shaping cohesion policy.

\section{Methods}

This study covers the problem of regional cohesion in the EU. In this framework, the regions are specified as level 2 units in the nomenclature for territorial units for statistics (NUTS 2) defined by Eurostat. The current version of the classification (NUTS 2016) distinguishes 281 regions at NUTS 2. However, due to data unavailability, the study concerned 278 regions (without 2 French regions: FRM0, FRY5 and 1 Finnish region: FI20) (Table 1).

In the first stage of the study, differences in general economic results in terms of regional GDP per capita were identified. These were calculated for 38503 pairs of regions in terms of monetary value (in euro) for 2017. It allowed conclusions about the scale of economic cohesion between the regions.

In the next stage, the structural features of the regional economies were diagnosed and compared in pairs. The structural characteristics were described in the employment dimensions for 2018. Employment distribution was analyzed across groups of sections of economic activity, NACE Rev. 2. The sections were grouped into 5 sectors based on their functional character:

- section A - agriculture,

- section $\mathrm{B}, \mathrm{C}, \mathrm{D}, \mathrm{E}, \mathrm{F}$ - industry,

- section G, H, I - classical services (less knowledge-intensive services),

- section J, K, L, M, N - financial and business services (knowledge-intensive market services),

- section O, P, Q, R, S, T, U - welfare services (knowledge-intensive non-market services).

In the analysis of the employment structure, percentage values for each sector were calculated. To take into consideration total differences in the structural features of each economy, Kukula's (1996) measure of structural differentiation was calculated, specified as:

$$
V=\frac{\sum_{i=1}^{k}\left|\alpha_{i}-\beta_{i}\right|}{2}
$$

where: $\alpha, \beta$ - structures of two objects (here: regions), $i(i=1, \ldots, k)$ - elements of the structures.

The measure adopts values from 0 to 1 (or can be presented as percentages). The higher the value, the more diversified are the two compared regions in terms of their sectoral structure of employment. 
All the regions were compared as pairs, with 38503 measures of structural differentiation being calculated.

To assess the features of the employment structure in a more detailed way, a concentration measure for each region was calculated (Kukuła, 1996):

$$
k=\frac{\sqrt{k}+k}{k-1} \sqrt{\sum_{i=1}^{k} \alpha_{i}^{2}}-\left(\frac{\sqrt{k}+k}{k-1}-1\right),
$$

where: $k$ - number of elements in the structure (here: $k=5$ ), $\alpha_{i}$ - the share of $i$ element in the structure.

A value equal to 0 means that all sectors have equal shares in the structure. The higher the value (up to 1 or $100 \%$ ), the more concentrated the analyzed structure is. This means that one sector gathers more resources and suggests potential specialization of the economy.

The differences in the economic results were then compared with the structural differences of employment engagement as well as their detailed features. It allowed conclusions about the interrelationships between economic structures and the results of the activities.

Moreover, all the regional economies were compared concerning their efficiency in transforming employment distributed by sectors into economic results, specified in total GDP. The DEA method (as developed by Charnes et al. (1978) and Färe and Lovell (1978)) was used to fulfill the task. The method allows a relative efficiency assessment of a set of comparable entities by linear programming techniques, in which a measurement of efficiency is defined as a ratio between the weighted sum of outputs and inputs (Poveda, 2011). Efficiency is measured in terms of radial or non-radial distance from the best unit on the production frontier, which is defined by the production function of the efficient units (Jain \& Natarajan, 2015). The DEA method does not require the specification of any particular functional form of relationships between multiply outputs and inputs. However, it makes necessary to specify both inputs and outputs and thus assume a direction of relation between them. The study assumes that labor engaged in different sectors is used to get regional GDP and thus efficiency is specified by labor productivity. As non-radial DEA does not assume any proportionality between inputs/outputs, a CCR input-oriented non-radial model was adopted to show the differences not only across the regions but also concerning the engagement of labor resources in each sector. The model allows to specify different efficiency of sectors using labor to produce. Thus, it indicated the most favorable sectors for economic development.

The inputs to the model were scales of employment (in thousands) in $5 \mathrm{sec}-$ tors in 2018, and the output: GDP (in million euro) in 2017. The EMS application was used for the calculations. The efficiency results from the model describe how much of the inputs was necessary to achieve the empirically obtained output using the best available technology in an optimal way. The higher the model result (up to 100\%), the more efficient the region is. 
In the final stage, the regional efficiency was compared to the structural features of the economies specified by sectoral concentration. It aimed to specify the attention paid on structural transformation within cohesion policy.

\section{Results}

\subsection{Sectoral structures of employment and economic cohesion between the EU regions}

The empirical investigation confirms that the regional level of development in the EU is highly diversified, inducing a need to implement a cohesion policy. In 2017 the average GDP per capita for the 278 regions was 28931 euro, with a range from 4600 euro in the poorest EU region (BG31) to 209900 euro in the most affluent one (UKI3). The coefficient of variation was about $60 \%$, and indicated serious interregional differences. Measured in terms of monetary value between pairs of regions, GDP per capita differences achieved an average of 16354 euro with a variation of $114 \%$. The highest difference was 205300 euro and confirmed strong differentiation in the results of economic activity and the standard of living of citizens. The observations paid attention to the determinants of such differences, some of which can be found in the structural features of the economies.

The average EU regions in 2018 were characterized by an employment structure typical for a developed service and knowledge-based economy. The highest share of employment was found in welfare services (about 32\%), followed by classical services (24\%), industry (24\%), knowledge-based market services $(15 \%)$ and agriculture (4\%). This means that more than $71 \%$ of human resources were engaged in a service sector, while agricultural employment was of marginal importance. Concerning the different kinds of services, it is important to note that knowledge-based services (both market and non-market) accounted for about $47 \%$ of total employment. These features prove that regional EU economies are generally structurally mature.

However, the EU regions appeared to be strongly diversified concerning their employment structures. Differences in the share of employment in each sector concerned mainly agriculture, where the variation coefficient exceeded 102\%. To exemplify the differences: in a Romanian region (RO21) agriculture accounted for $42 \%$ of employment, while in some urban regions (mainly capital cities) the share was close to 0\% (e.g. UKI3, HU11, FR10, BE10, ES63).

The quite serious interregional differences included shares of employment in industry and knowledge-based market services, with about 34\% and 35\% variation respectively. Industry played an especially important role in employment in the regions, e.g. Romania (RO42 - 48\%), Hungary (HU21 - 45\%), Czechia (CZ05, CZ07 - 45\%) and Slovakia (SK02 - 44\%), while the least industrialized regions were found in Spain (ES64, ES63 - 7\%) and the UK 
(UKI3, UKI4 - 8\%). The share of industrial employment may be induced by some specific features of a region, such as natural environment characteristics as well as be perceived as a sign of poor structural development advancement in a direction towards a weightless economy model. Nowadays, deindustrialization is a process specified as typical for advanced economies.

Contrary to industrial employment, a high share of knowledge-based market services is recognized as a main indicator of structural development. In these terms, regions in Romania (RO41, RO21, RO22), Greece (EL63, EL53, EL65), Hungary (HU23, HU31, HU32) and Bulgaria (BG31, BG42) achieved the poorest results with shares in the range $4-7 \%$. On the other hand, the group of leading regions include parts of London (UKI3, UKI4, UKI6, UKI7, UKI5), Stockholm (SEll) or Paris (FR10) with employment exceeding 30\% (up to 45\% in UKI3) in financial and business services.

The slightest differences were found in welfare services, with a variation of $16 \%$, and just followed by classical services, with a $19 \%$ variation. Some peripheral French and Spanish regions (FRY1, FRY2, ES64, FRY3, FRY4, ES63) exhibited the highest role of non-market services with an employment share of around 50\%, while in some Romanian regions (RO21, RO42) the share was lower than $15 \%$.

Employment in classical services accounted for about a half of the total employment in some Greek or Spanish regions (EL62, EL42, ES70). On the other hand, these traditional kinds of activity engaged about $15 \%$ of the labor in London (UKI3) and Luxembourg (LU00).

The structural features of a regional economy can be perceived as important indicators of the general level of development. This is confirmed by statistically essential correlations between the share of employment in each sector and the level of GDP per capita across the EU regions (Table 2). The indicator was negative for employment in agriculture, industry and classical services, while positive for knowledge-based market services and welfare services. The strongest relationships were identified for knowledge-based market services, and this sector in particular may be treated as an indicator of the structural advancement of the regional economy. On the other hand, agricultural employment plays a marginal role in developed economies. The observations are in line with the theory of structural development that indicates trends in deagrarization, deindustrialization, and service knowledge-based economy development.

Another important feature of a structure is its level of concentration. For the EU regions, the least concentrated structures were found in some Polish (PL81, PL84, PL72, PL92), Greek (EL64, EL53), Spanish (ES62) and Italian (ITF4) regions, where the concentration measure did not exceed 6\%. On the other hand, the highest structural concentration was observed in Spanish (ES63, ES64) and Greek (EL62, EL42) regions with a concentration measure above $25 \%$. The average level was about $12 \%$ with a variation of about $31 \%$.

There is an important question connected with the pattern of structural transformations that supports economic development. Should development be 
specified by a more concentrated structural pattern that leads to specialization or should it rather balance the employment distribution with more equal shares for each sector? The correlation coefficient between the measure of concentration of structures and GDP per capita across the 278 EU regions suggests the former pattern, as it takes a positive value (statistically significant). The higher the GDP per capita, the more concentrated is the structure of employment. However, the relationship is rather moderate (0.23), suggesting diversified possibilities of structural transformation.

Moreover, an essential issue arises concerning the relations between the structural differences between regions and the differences in their level of GDP per capita. If structural convergence took place, the more similar the structures found in comparable regions, the more equal should be the level of GDP per capita between them. In other words, the differences should vanish simultaneously in the dimensions of the sectoral structures of employment and levels of GDP per capita.

Comparisons of the employment structures in pairs of regions using Kukuta's measure of differentiation indicate that the average differentiation in a pair of regions was about $16.4 \%$. Nevertheless, the results varied concerning different pairs and the coefficient of variation was $52 \%$. The most distinct structures were noted for the pair UKI3 and RO21, where the differentiation measure was $59.3 \%$.

Correlation between structural differentiation and differences in level of GDP per capita for pairs of regions appears to be statistically significant, with the expected (positive) result. This was 0.37 and proved that higher structural differences equate to higher differences in GDP per capita. It confirms the initial hypothesis about the relations existing between structural features of regional economies and economic cohesion. However, as the variation of GDP per capita differences $(114 \%)$ is higher than the variation of structural differences $(52 \%)$, the structural characteristics are only one of many factors needed to explain regional developmental differences. Moreover, the results do not indicate a direction of causality which may be mutual and compound.

\subsection{Economic efficiency of the EU regions}

Efficiency of regional economies may be compared by describing how labor resources are used to achieve the highest possible production. However, the efficiency depends on many factors such as quality of labor resources, capital equipment and available infrastructure, technology used or institutional solutions - to list but a few of many important ones. Considering regional efficiency the paper focuses on the sectoral distribution of labor as one of the determinants of economic results in terms of GDP. Thus we examine not only general efficiency of economies (labor productivity) but also compare the results gained from employment in each sector of economic activity. 
Usage of the DEA-CCR-NR input-oriented model gave conclusions about the generally low economic efficiency of regions when transforming employment into GDP (Table 3), with an average efficiency of only $16.5 \%$. It suggests that by using the best available technology, more than $83 \%$ of the labor engaged would not be necessary to achieve the observed economic results. Obviously, some regions achieve better and some worse efficiency results. The coefficient of variation for efficiency is 61\%. Some Bulgarian regions (BG33, BG32) achieved efficiency results of under 5\%, while Irish (IE05) and British (UKI3) regions were fully efficient.

From the point of view of the main aim of the paper, the most important issue is connected with efficiencies gained when using labor in different sectors. The highest efficiency was found in knowledge-based market services (regional average of $47 \%$ ) and it was the only kind of activity that appeared to be more efficient than the total result. Moreover, the variation between regions was the lowest, at $34 \%$, suggesting a similar leading role of the sector for development of every regional economy. Just slightly below the total result was the efficiency in welfare service $(16.3 \%)$, where the variation was slightly above the total variation as well. This was followed by another part of the service sector - classical services (10.8\%). The poorest efficiency was noted for agriculture, which achieved only $1.4 \%$ of the possible with a common technology and was the most diversified (with a coefficient of variation of 755\%). The efficiency of industry also appeared to be low, with an average level of $6.8 \%$ and high variation (155\%). Generally, the results confirm the necessity of structural transformation in the direction towards a knowledge-based service economy with a leading role by financial and business services and a need to reduce the role of agriculture.

Moreover, the efficiency results correlated positively with the concentration of the employment structure (0.27). It additionally supports the thesis about concentration as a more favorable pattern of structural transformation in the EU regions.

\section{Conclusions}

The main findings of the study confirm the existence of positive relation between regional economic cohesion in terms of production level (GDP per capita) and sectoral structure of employment. They revealed that diversification between regions were mutually strengthened in the two analyzed economic dimensions. Nevertheless, any conclusions about the relationship should be treated in a cautious manner. Structural characteristics seem to constitute only one of many factors required to explain regional developmental differences. Moreover, the causality between sectoral structure and GDP level may be mutual and compound and requires further research.

The diagnosis of sectoral structure of the EU regions specified an average one as being structurally mature, with a prevailing share of service employment, 
especially knowledge-intensive, and the marginal importance of agriculture. The observation is in line with a theory of structural development that indicates the trends toward deagrarization, deindustrialization, and service knowledge-based economy development

However, the diagnosis of regional cohesion in the EU revealed strong disparities in the economic results and the structural features. Interregional structural differences were found mainly in the role of agriculture. This fact to some extent justifies the role of agricultural policy in the European system. Nevertheless, the policy should not limit the universal trend to employment deagrarization but rather support agricultural efficiency.

Moreover, knowledge-based market services appear the most favorable for economic results in terms of GDP. This sector may be treated as an indicator of the structural advancement of regional economy and a new growth pole. Policy measures should thus support its development across all the territorial units to avoid regional peripherization.

Additional findings lay in the contribution to the discussion concerning specialization - diversification. The research indicates favorable results for structural concentration that coexists with both a high GDP per capita level as well as economic efficiency (labor productivity). Nevertheless, the results consider only broadly defined economic sectors and rather indicate direction of structural transformation instead of strict specialization. In the research, growing concentration is specified mainly by an outflow of labor from agriculture. An issue of specialization in a more detailed approach to the kinds of activities may be an interesting field for future research.

\section{References}

Baumol, W.J. (1967). Macroeconomics of unbalanced growth: the anatomy of urban crisis. The American Economic Review, 57(3).

Bierbaumer-Polly, J., Huber, P., \& Rozmahel, P. (2016). Regional business-cycle synchronization, sector specialization and EU accession. Journal of Common Market Studies, 54(3). doi:10.1111/jcms.12296.

Charnes, A., Cooper, W.W., \& Rhodes, E. (1978). Measuring the efficiency of decision making units. European Journal of Operational Research, 2(6). doi:10.1016/0377-2217(78)90138-8.

Chenery, H.B. (1971). Growth and structural change. Finance and Development, $8(3)$.

Clark, C. (1940). The conditions of economic progress. London: Macmillan.

Eurostat. (2020). Retrieved 28.01.2020 from https://ec.europa.eu.

Färe, R., \& Lovell, C. (1978). Measuring the technical efficiency of production. Journal of Economic Theory, 19(1). doi:10.1016/0022-0531(78)90060-1.

Fisher, A.B.G. (1935). The clash of progress and security. London: Macmillan.

Fourastié, J. (1949). Le grand espoir du XXème siècle. Paris: PUF. 
Fuchs, V.R. (1965). The growing importance of the service industries. The Journal of Business, 38(4). doi:10.1086/294801.

Guastella, G., \& Timpano, F. (2016). Knowledge, innovation, agglomeration and regional convergence in the EU: motivating place-based regional intervention. Review of Regional Research, 36(2). doi:10.1007/s10037-015-0104-x.

Iordan, M., Chilian, M.-N., \& Ciurariu, G. (2017). Post-crisis changes in the sectoral and occupational employment structures of the Romanian labor market. Economy Transdisciplinarity Cognition, 20(2).

Jain, R.K., \& Natarajan, R. (2015). A DEA study of airlines in India. Asia Pacific Management Review, 20(4). doi:10.1016/j.apmrv.2015.03.004.

Kallioras, D., \& Petrakos, G. (2010). Industrial growth, economic integration and structural change: evidence from the EU new member-states regions. The Annals of Regional Science, 45(3). doi:10.1007/s00168-009-0296-5.

Klodt, H. (1995). Productivity growth in service and non-service industries: implications for convergence. In E. Felli, F.C. Rosati, \& G. Tria (Eds.), The service sector: productivity and growth. Rome: Physica-Verlag. doi:10.1007/978-3-642-49999-9_9.

Krieger-Boden, Ch. (2004). Regional structural change and cohesion in the process of European integration: a comparison of French, German, Portuguese and Spanish regions. Retrieved 20.03.2021 from http://hdl.handle.net.

Krugman, P (1991). Increasing returns and economic geography. Journal of Political Economy, 99(3). doi:10.1086/261763.

Kukuła, K. (1996). Statystyczne metody analizy struktur ekonomicznych. Kraków: Wydawnictwo Edukacyjne.

Kuznets, S. (1966). Modern economic growth: rate, structure and spread. New Haven-London: Yale University Press.

Longhi, Ch., \& Musolesi, A. (2007). European cities in the process of economic integration: towards structural convergence. The Annals of Regional Science, 4l(2). doi:10.1007/s00168-006-0104-4.

Molle, W., \& Boeckhout, S. (1995). Economic disparity under conditions of integration: a long term view of the European case. Papers in Regional Science, 74 (2). doi:10.1111/j.1435-5597.1995.tb00631.x.

Monfort, P. (2008). Convergence of EU regions: measures and evolution. European Union Regional Policy Working Papers, (1).

Neculita, M., \& Sarpe, D.A. (2019). Convergence through Regionalization. Annals of "Dunarea de Jos" University of Galati, Fascicle I. Economics and Applied Informatics, 25(1). doi:10.35219/eail58404092.

Poveda, A.C. (2011). Economic development and growth in Colombia: an empirical analysis with super-efficiency DEA and panel data models. Socio-Economic Planning Sciences, 45(4). doi:10.1016/j.seps.2011.07.003.

Rowthorn, R., \& Ramaswamy, R. (1997). Deindustrilization: its causes and implications. Economic Issues, 10. 
Sassi, M. (2011). Convergence across the EU regions: economic composition and structural transformation. International Advances in Economic Research, 17(1). doi:10.1007/s11294-010-9286-8.

Wacziarg, R. (2001). Structural convergence. Stanford University CDDRL Working Paper, (8).

\section{Acknowledgements}

Author contributions: author has given an approval to the final version of the article.

Funding: this research was fully funded by the University of Rzeszów.

Note: the results of this study were presented at 9th Scientific Conference: Contemporary Economic Problems 'Thirty years of transformation' (September, 16, 2020, Poland, online). 


\section{Appendix}

Table 1.

List of the researched NUTS 2 regions of the EU-28

\begin{tabular}{|c|c|}
\hline The EU-28 state & NUTS 2 region \\
\hline Belgium & $\begin{array}{l}\text { BE10 - Région de Bruxelles-Capitale / Brussels Hoofdstedelijk Gewest; BE21 - Prov. } \\
\text { Antwerpen; BE22 - Prov. Limburg (BE); BE23 - Prov. Oost-Vlaanderen; BE24 - Prov. } \\
\text { Vlaams-Brabant; BE25 - Prov. West-Vlaanderen; BE31 - Prov. Brabant wallon; BE32 - } \\
\text { Prov. Hainaut; BE33 - Prov. Liège; BE34 - Prov. Luxembourg (BE); BE35 - Prov. } \\
\text { Namur }\end{array}$ \\
\hline Bulgaria & $\begin{array}{l}\text { BG31 — Severozapaden; BG32 — Severen tsentralen; BG33 — Severoiztochen; BG34 - } \\
\text { Yugoiztochen; BG41 — Yugozapaden; BG42 — Yuzhen tsentralen }\end{array}$ \\
\hline $\begin{array}{l}\text { the Czech } \\
\text { Republic }\end{array}$ & $\begin{array}{l}\text { CZ01 - Praha; CZ02 — Strední Cechy; CZ03 — Jihozápad; CZ04 — Severozápad; } \\
\text { CZ05 - Severovýchod; CZ06 — Jihovýchod; CZ07 — Strední Morava; CZ08 - } \\
\text { Moravskoslezsko }\end{array}$ \\
\hline Denmark & $\begin{array}{l}\text { DK01 — Hovedstaden; DK02 — Sjælland; DK03 — Syddanmark; DK04 — Midtjylland; } \\
\text { DK05 - Nordjylland }\end{array}$ \\
\hline Germany & 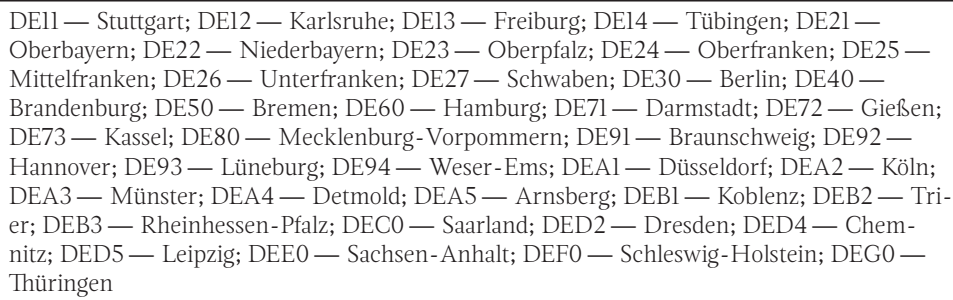 \\
\hline Estonia & EE00 - Eesti \\
\hline Ireland & IE04 - Northern and Western; IE05 — Southern; IE06 - Eastern and Midland \\
\hline Greece & $\begin{array}{l}\text { EL51 - Anatoliki Makedonia, Thraki; EL52 - Kentriki Makedonia; EL53 - Dytiki } \\
\text { Makedonia; EL54 - Ipeiros; EL61 - Thessalia; EL62 - Ionia Nisia; EL63 - Dytiki Ellada; } \\
\text { EL64 - Sterea Ellada; EL65 - Peloponnisos; EL30 - Attiki; EL41 - Voreio Aigaio; } \\
\text { EL42 - Notio Aigaio; EL43 - Kriti }\end{array}$ \\
\hline Spain & $\begin{array}{l}\text { ES11 - Galicia; ES12 — Principado de Asturias; ES13 - Cantabria; ES21 - País Vasco; } \\
\text { ES22 - Comunidad Foral de Navarra; ES23 - La Rioja; ES24 - Aragón; ES30 - Comuni- } \\
\text { dad de Madrid; ES41 - Castilla y León; ES42 - Castilla-la Mancha; ES43 - Extremadura; } \\
\text { ES51 - Cataluña; ES52 - Comunidad Valenciana; ES53 - Illes Balears; ES61 - Andalucía; } \\
\text { ES62 - Región de Murcia; ES63 - Ciudad Autónoma de Ceuta (ES); ES64 - Ciudad } \\
\text { Autónoma de Melilla (ES); ES70 — Canarias (ES) }\end{array}$ \\
\hline France & 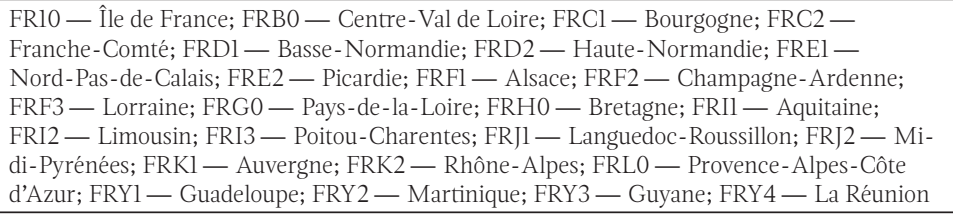 \\
\hline Croatia & HR03 - Jadranska Hrvatska; HR04 - Kontinentalna Hrvatska \\
\hline Italy & $\begin{array}{l}\text { ITCl - Piemonte; ITC2 - Valle d’Aosta/Vallé d’Aoste; ITC3 - Liguria; ITC4 - Lom- } \\
\text { bardia; ITH1 - Provincia Autonoma di Bolzano/Bozen; ITH2 - Provincia Autonoma di } \\
\text { Trento; ITH3 - Veneto; ITH4 - Friuli-Venezia Giulia; ITH5 - Emilia-Romagna; ITIl — } \\
\text { Toscana; ITI2 - Umbria; ITI3 - Marche; ITI4 - Lazio; ITFl — Abruzzo; ITF2 - Molise; } \\
\text { ITF3 — Campania; ITF4 - Puglia; ITF5 - Basilicata; ITF6 - Calabria; ITGl — Sicilia; } \\
\text { ITG2 - Sardegna }\end{array}$ \\
\hline Cyprus & CY00 - Kypros \\
\hline Latvia & LV00 - Latvija \\
\hline
\end{tabular}




\begin{tabular}{|c|c|}
\hline The EU-28 state & NUTS 2 region \\
\hline Lithuania & LT01 — Sostines regionas; LT02 — Vidurio ir vakaru Lietuvos regionas \\
\hline Luxembourg & LU00 - Luxembourg \\
\hline Hungary & $\begin{array}{l}\text { HU11 — Budapest; HU12 — Pest; HU21 — Közép-Dunántúl; HU22 — Nyugat-Dunántúl; } \\
\text { HU23 - Dél-Dunántúl; HU31 — Észak-Magyarország; HU32 — Észak-Alföld; HU33 — } \\
\text { Dél-Alföld }\end{array}$ \\
\hline Malta & MT00 - Malta \\
\hline the Netherlands & $\begin{array}{l}\text { NL11 - Groningen; NL12 - Friesland (NL); NL13 - Drenthe; NL21 - Overijssel; } \\
\text { NL22 - Gelderland; NL23 - Flevoland; NL31 - Utrecht; NL32 - Noord-Holland; } \\
\text { NL33 - Zuid-Holland; NL34 - Zeeland; NL41 - Noord-Brabant; NL42 - Limburg } \\
\text { (NL) }\end{array}$ \\
\hline Austria & $\begin{array}{l}\text { AT1l - Burgenland (AT); AT12 - Niederösterreich; AT13 - Wien; AT21 - Kärnten; } \\
\text { AT22 - Steiermark; AT31 — Oberösterreich; AT32 - Salzburg; AT33 - Tirol; AT34 — } \\
\text { Vorarlberg }\end{array}$ \\
\hline Poland & $\begin{array}{l}\text { PL21 - Malopolskie; PL22 — Slaskie; PL41 — Wielkopolskie; PL42 - Zachodniopomorsk- } \\
\text { ie; PL43 - Lubuskie; PL51 — Dolnoslaskie; PL52 - Opolskie; PL61 - Kujawsko-Pomorsk- } \\
\text { ie; PL62 - Warminsko-Mazurskie; PL63 - Pomorskie; PL71 — Lódzkie; PL72 - Swieto- } \\
\text { krzyskie; PL81 - Lubelskie; PL82 - Podkarpackie; PL84 - Podlaskie; PL91 — Warszawski } \\
\text { stoleczny; PL92 - Mazowiecki regionalny }\end{array}$ \\
\hline Portugal & $\begin{array}{l}\text { PTll — Norte; PT15 — Algarve; PTl6 — Centro (PT); PT17 — Área Metropolitana de } \\
\text { Lisboa; PT18 - Alentejo; PT20 — Região Autónoma dos Açores (PT); PT30 - Região } \\
\text { Autónoma da Madeira (PT) }\end{array}$ \\
\hline Romania & $\begin{array}{l}\text { ROll - Nord-Vest; RO12 — Centru; RO21 - Nord-Est; RO22 — Sud-Est; RO31 - } \\
\text { Sud-Muntenia; RO32 - Bucuresti-Ilfov; RO41 — Sud-Vest Oltenia; RO42 — Vest }\end{array}$ \\
\hline Slovenia & SI03 - Vzhodna Slovenija; SI04 - Zahodna Slovenija \\
\hline Slovakia & $\begin{array}{l}\text { SK01 — Bratislavský kraj; SK02 — Západné Slovensko; SK03 — Stredné Slovensko; } \\
\text { SK04 — Východné Slovensko }\end{array}$ \\
\hline Finland & $\begin{array}{l}\text { FI19 — Länsi-Suomi; FIlB — Helsinki-Uusimaa; FIlC — Etelä-Suomi; FIlD — Pohjois-ja } \\
\text { Itä-Suomi }\end{array}$ \\
\hline Sweden & $\begin{array}{l}\text { SEll — Stockholm; SE12 — Östra Mellansverige; SE21 — Småland med öarna; SE22 — } \\
\text { Sydsverige; SE23 - Västsverige; SE31 - Norra Mellansverige; SE32 - Mellersta Norrland; } \\
\text { SE33 - Övre Norrland }\end{array}$ \\
\hline $\begin{array}{l}\text { the United } \\
\text { Kingdom }\end{array}$ & 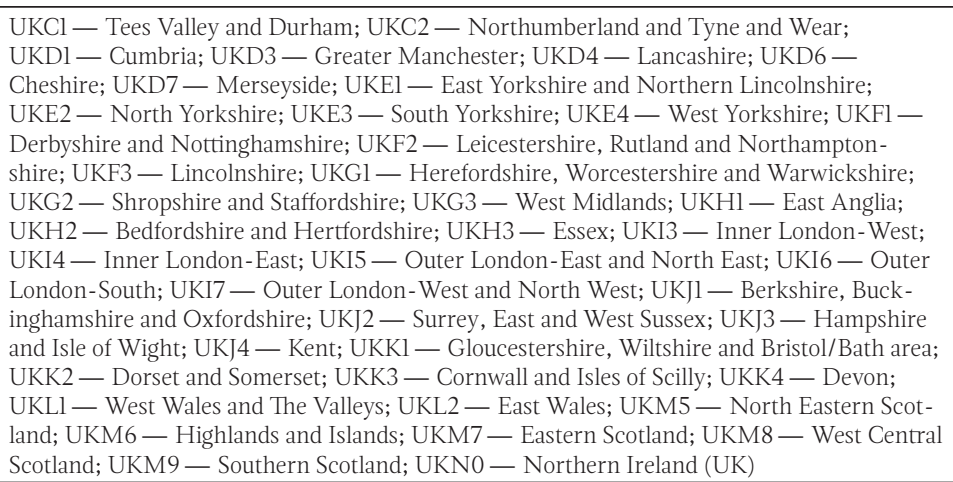 \\
\hline
\end{tabular}

Source: Own preparation based on Eurostat (2020). 
Table 2.

Share of employment in 5 sectors (groups of sections) in 278 EU regions in 2018 (\%) and the correlation coefficients between GDP per capita (2017) and structural features

\begin{tabular}{|c|c|c|c|c|c|}
\hline Specification & $\begin{array}{l}\text { Agriculture } \\
\text { (A) }\end{array}$ & $\begin{array}{l}\text { Industry } \\
\text { (BCDEF) }\end{array}$ & $\begin{array}{c}\text { Classical } \\
\text { services (GHI) }\end{array}$ & $\begin{array}{c}\text { Knowledge-intensive } \\
\text { market services (JKLMN) }\end{array}$ & $\begin{array}{c}\text { Welfare services } \\
\text { (OPQRSTU) }\end{array}$ \\
\hline avg. & 4.41 & 24.14 & 24.40 & 15.40 & 31.64 \\
\hline cf. var. & 102.15 & 34.36 & 18.78 & 34.76 & 17.06 \\
\hline $\min$ & 0.00 & 7.29 & 14.98 & 4.23 & 13.54 \\
\hline $\max$ & 41.85 & 47.72 & 53.19 & 45.34 & 51.48 \\
\hline $\begin{array}{l}\text { regions with } \\
\text { the lowest } \\
\text { shares }\end{array}$ & $\begin{array}{l}\text { ES63, UKI3, } \\
\text { BE10, HU11, } \\
\text { UKI5 }\end{array}$ & $\begin{array}{l}\text { ES64, ES63, } \\
\text { UKI3, UKI4, } \\
\text { ES70 }\end{array}$ & $\begin{array}{l}\text { UKI3, LU00, } \\
\text { FRY3, FRK1, } \\
\text { SE31 }\end{array}$ & $\begin{array}{l}\text { RO41, RO21, RO22, } \\
\text { EL63, EL53 }\end{array}$ & $\begin{array}{l}\text { RO21, RO42, } \\
\text { RO41, RO31, } \\
\text { RO1l }\end{array}$ \\
\hline $\begin{array}{l}\text { regions with } \\
\text { the highest } \\
\text { shares }\end{array}$ & $\begin{array}{l}\text { RO21, RO41, } \\
\text { EL63, EL65, } \\
\text { EL51 }\end{array}$ & $\begin{array}{l}\text { RO42, HU21, } \\
\text { CZ05, CZ07, } \\
\text { SK02 }\end{array}$ & $\begin{array}{l}\text { EL62, EL42, } \\
\text { ES70, ES53, } \\
\text { PT15 }\end{array}$ & $\begin{array}{l}\text { UKI3, UKI4, UKI6, SEll, } \\
\text { UKI7 }\end{array}$ & $\begin{array}{l}\text { ES63, FRY4, } \\
\text { FRY3, ES64, } \\
\text { FRY2 }\end{array}$ \\
\hline \multicolumn{6}{|c|}{ correlation: GDP per capita } \\
\hline $\begin{array}{l}\text { employment } \\
\text { share }\end{array}$ & $-0.4561^{*}$ & $-0.3219^{*}$ & $-0.2344^{*}$ & $0.6871^{*}$ & $0.3195^{*}$ \\
\hline $\begin{array}{l}\text { concentration } \\
\text { of structure }\end{array}$ & \multicolumn{5}{|c|}{$0.2314^{*}$} \\
\hline
\end{tabular}

Note:

*statistically significant at 0.01 .

Source: Own preparation based on Eurostat (2020).

Table 3.

Efficiency results for the EU 278 regions — DEA-CCR-NR input-oriented model (\%)

\begin{tabular}{lccccrr}
\hline Specification & $\begin{array}{c}\text { Agriculture } \\
(\mathrm{A})\end{array}$ & $\begin{array}{c}\text { Industry } \\
(\mathrm{BCDEF})\end{array}$ & $\begin{array}{c}\text { Classical } \\
\text { services (GHI) }\end{array}$ & $\begin{array}{c}\text { Knowledge-intensive } \\
\text { market services (JKLMN) }\end{array}$ & $\begin{array}{c}\text { Welfare services } \\
\text { (OPQRSTU) }\end{array}$ & Total \\
\hline avg. & 1.37 & 6.81 & 10.80 & 46.97 & 16.28 & 16.45 \\
cf. var. & 755 & 155 & 98 & 34 & 65 & 61 \\
\hline
\end{tabular}

Source: Own preparation based on Eurostat (2020). 
